\title{
Studies on natural agglutinins for chicken red cells in sera of inbred mice
}

\author{
Misao KanemaKi* \\ (Laboratory of Animal Genetics, Faculty of Agriculture, \\ Nagoya University, Nagoya)
}

(Received for Publication on November 6, 1970)

There are many reports on the presence of natural agglutinins for the red cells of several animals in normal mouse sera. Natural agglutinins for sheep and chicken red cells in 12 inbred strains of mice were searched by STERN and DAVIDSOHN ${ }^{8}$, who showed that there existed significant strain differences in the incidences and titers of the agglutinins. STERN et al.99 demonstrated that the presence and level of the natural anti-sheep agglutinin were under genetic control. Whereas, STimphing ${ }^{(0)}$ reported that the incidences and titers of natural agglutinins for sheep and chicken red cells in C57BL mouse sera fluctuated with age of mice and the females had higher titers than the males. Kirshвом and HoвскER ${ }^{4)}$ showed the similar sex difference in C57BL mice in regard to natural agglutinins for human red cells.

HAYAKAWA and $K_{O N D O^{3}}$ found that the agglutinating capacity of the mouse sera differed markedly depending upon the chicken red cells used for agglutinogen, that is, the mouse sera which failed to agglutinate the red cells from line B of Nagoya breed showed strongly positive reaction with the red cells from Jito group of chicken.

The purpose of this experiment is to classify the mouse strains in regard to the appearance of natural agglutinins for different chicken red cells from three inbred strains, considering the factors which may influence the intrastrain variations such as sex or age. Moreover, the qualitative differences among three mouse agglutinins for chicken red cells are analysed.

\section{Materials and Methods}

Inbred mice: The mice from which the sera were obtained belonged to seven inbred strains (DDK, KK, NC, BS, AIII, AY and C57BL/6) being maintained in our laboratory. DDK, $\mathrm{KK}$ and NC were established by KoNDo et $a l .^{51}$, BS, AIII and AY were established in our laboratory in 1965, and C57BL/6 was derived from Kyoto University in 1964. AY mice were maintained as forced heterozygocity for coat colour genotypes, $\mathrm{A} / \mathrm{A}$ and $\mathrm{A}^{\mathrm{y}} / \mathrm{A}$, and segregated non-yellow mice were used in this work.

Mouse serum: The blood was obtained from mouse by puncture of the retroorbital sinus, or by decapitation, and allowed to clot. The serum was separated by centrifugation at 2,000 $\mathrm{rpm}$ for 5 minutes, and stored at $-20^{\circ} \mathrm{C}$ before using for agglutination test.

Chicken: The following chicken breeds or strains were used for obtaining the red cells:

* Present adaress, Holstein Cattle Association of Japan, Honcho 4-38-13, Nakano-ku, Tokyo 
Natural agglutinins in mouse sera

White Leghorn (WL), Black Minorca-C (BM-C), Rhode Island Red (RIR), Nagoya-A and -B (NG-A and NG-B), Mikawa (MK), Sebrite Bantam (SB), Tokara Jidori (TJ) and our strain CON (bred from crossbreds between White Cornish and New Hampshire) and GOS (bred from a mixed origin of Jitokko, NG-A, SB and Goshiki Shokoku). These chicken strains or breeds were maintained in our laboratory, and their blood types were examined by FuJ10 ${ }^{2)}$.

Chicken red cells: Blood was obtained from wing vein of adult chickens, and washed three times with saline. Two per cent suspension of red cells in saline was used for agglutination test.

Agglutination test: Approximately $0.05 \mathrm{~m} l$ of normal sera were mixed with equal volume of chicken red cell suspension on the plastic agglutination plate. At one hour after shaking, the agglutination patterns were recorded.

\section{Results}

1. Difference of agglutinability of chicken red cells with mouse sera

The red cells from various breeds or strains of chicken which had been examined for the blood types were tested for their agglutinability with pooled normal sera from seven strains of mice. The results were shown in Table 1. Seven red cells which belonged to two inbred strains (NG-A and WL) and two breeds (TJ and SB) were strongly agglutinated with almost

Table 1. Comparison of agglutination reactions of natural anti-chicken red cell antibodies in sera of mouse with chicken blood types

\begin{tabular}{|c|c|c|c|c|c|c|c|c|c|c|c|c|}
\hline \multicolumn{3}{|c|}{ Chicken red cells } & \multicolumn{2}{|c|}{$\begin{array}{c}\text { Chicken blood } \\
\text { type systems }\end{array}$} & \multirow{2}{*}{$\begin{array}{c}\text { Agglutinability } \\
\text { with } \\
\text { cattle serum }\end{array}$} & \multicolumn{4}{|c|}{ Agglutination titers** } & \multicolumn{2}{|c|}{ with mouse } & \multirow{2}{*}{$\frac{\text { erum }}{\mathrm{AY}}$} \\
\hline No. & Strain & Sex & A & $\mathrm{B}$ & & $\mathrm{KK}$ & $\mathrm{NC}$ & $\mathrm{C} 57 \mathrm{BL}$ & $\mathrm{BS}$ & DDK & AIII & \\
\hline 1 & $\mathrm{NG}-\mathrm{A}$ & $\mathrm{F}$ & $\mathbf{P}$ & $\mathrm{b}$ & H & 8 & 4 & 4 & 4 & 16 & 2 & 0 \\
\hline 2 & $\mathrm{NG}-\mathrm{A}$ & $\mathrm{F}$ & $\mathrm{P}$ & $\mathrm{b}$ & $H$ & 8 & 4 & 8 & 4 & 16 & 2 & 0 \\
\hline 3 & $W L-G$ & $\mathbf{F}$ & $\mathrm{P}$ & G & + & 4 & 2 & 4 & 4 & 4 & 2 & 0 \\
\hline 4 & WL-Gr & $\mathbf{F}$ & $\mathrm{P}$ & $\mathrm{G}$ & + & 4 & 2 & 2 & 4 & 8 & 0 & 0 \\
\hline 5 & $\mathrm{TJ}^{*}$ & $\mathrm{~F}$ & $\mathrm{P}$ & $\mathrm{M}$ & 世 & 8 & 2 & 4 & 4 & 16 & 2 & 0 \\
\hline 6 & $\mathrm{TJ}^{*}$ & $\mathrm{~F}$ & $\mathrm{P}$ & $\mathrm{M}$ & H & 8 & 2 & 4 & 4 & 16 & 2 & 0 \\
\hline 7 & $\mathrm{MK}^{*}$ & $\mathrm{~F}$ & $\mathrm{P}$ & $\mathrm{b}$ & + & 2 & 0 & 0 & 0 & 2 & 0 & 0 \\
\hline 8 & $\mathrm{MK}^{*}$ & $\mathrm{~F}$ & $\mathrm{P}$ & $\mathrm{b}$ & + & 2 & 0 & 0 & 0 & 2 & 0 & 0 \\
\hline 9 & GOS & $\mathrm{F}$ & $\mathrm{P}$ & $b$ & - & 2 & 0 & 0 & 0 & 4 & 0 & 0 \\
\hline 10 & GOS & $\mathrm{F}$ & $\mathbf{P}$ & $\mathrm{b}$ & - & 2 & 0 & 0 & 0 & 8 & 0 & 0 \\
\hline 11 & $\mathrm{SB}^{*}$ & $\mathrm{M}$ & $P$ & A & $H$ & 16 & 4 & 4 & 8 & 16 & 4 & 2 \\
\hline 12 & $\mathrm{SB}^{*}$ & $\mathrm{~F}$ & $a$ & $\mathrm{AG}$ & - & 2 & 0 & 0 & 0 & 0 & 0 & 0 \\
\hline 13 & $\mathrm{NG}-\mathrm{B}$ & $\mathbf{M}$ & $\mathbf{a}$ & B & + & 4 & 0 & 2 & 0 & 0 & 0 & 0 \\
\hline 14 & $N G-B$ & M & a & $\mathrm{B}$ & + & 8 & 0 & 2 & 0 & 0 & 0 & 0 \\
\hline 15 & $\mathrm{CON}$ & $\mathrm{F}$ & a & $\mathrm{K}$ & - & 0 & 0 & 0 & 0 & 0 & 0 & 0 \\
\hline 16 & $\mathrm{CON}$ & $\mathrm{F}$ & $\mathrm{a}$ & $\mathrm{K}$ & - & 2 & 0 & 2. & 0 & 4 & 0 & 0 \\
\hline 17 & RIR* & M & $\mathrm{a}$ & $\mathrm{G}$ & + & 2 & 0 & 0 & 0 & 0 & 0 & 0 \\
\hline 18 & RIR* $^{*}$ & $\mathrm{~F}$ & $\mathrm{a}$ & $\mathrm{G}$ & - & 2 & 0 & 0 & 0 & 0 & 0 & 0 \\
\hline 19 & $\mathrm{BM}-\mathrm{C}$ & $F$ & $\mathbf{a}$ & $\mathrm{A}$ & - & 0 & 0 & 0 & 0 & 0 & 0 & 0 \\
\hline 20 & $\mathrm{BM}-\mathrm{C}$ & $\mathrm{F}$ & $\mathrm{a}$ & A & - & 0 & 0 & 0 & 0 & 0 & 0 & 0 \\
\hline
\end{tabular}

* These chickens belonged to non-inbred breads, but to closed populations

** For the red cells which failed to agglutinate with two fold diluted sera, the zero scores are given 


\section{KANEMAKI}

Table 2. Agglutinability of red cells of three chicken strains with pooled mouse sera

\begin{tabular}{|c|c|c|c|c|c|c|c|}
\hline \multirow{3}{*}{ Strains of chicken } & \multirow{3}{*}{ No. tested } & \multicolumn{6}{|c|}{$\begin{array}{l}\text { Number of chicken which showed different } \\
\text { agglutinability with pooled sera of* }\end{array}$} \\
\hline & & \multicolumn{3}{|c|}{ KK } & \multicolumn{2}{|c|}{ DDK } & \multirow[b]{2}{*}{-} \\
\hline & & $H$ & \pm & - & H & \pm & \\
\hline $\mathrm{NG}-\mathrm{A}$ & 4 & 4 & 0 & 0 & 4 & 0 & 0 \\
\hline$N G-B$ & 19 & 16 & 3 & 0 & 0 & 5 & 14 \\
\hline $\mathrm{BM}-\mathrm{C}$ & 8 & 0 & 1 & 7 & 0 & 0 & 8 \\
\hline
\end{tabular}

* Ht: strongly agglutinated, \pm : doubtfly agglutinated, -: not agglutinated

all of mouse sera, the red cells which belonged to three inbred strains (NG-B, GOS and CON) and three breeds (MK, RIR and SB) were agglutinated with some mouse sera, and the remaining three red cells which belonged to two inbred strains (BM-C and CON) were not agglutinated with any mouse sera. Thus, chicken red cells were classified into three types on the agglutination reactions with normal mouse sera.

The difference of the agglutinability of chicken red cells within strain was examined for some individuals of three inbred chickens, NG-A, NG-B and BM-C (Table 2). From Tables 1 and 2, it may be confirmed that among the individuals within inbred strain of chicken a similar agglutinability of red cells was observed, while different degrees of agglutinability were recorded among the individuals of each non-inbred breed.

In the following tests, the red cells from some individuals of the three inbred chickens, $\mathrm{NG}-\mathrm{A}, \mathrm{NG}-\mathrm{B}$ and $\mathrm{BM}-\mathrm{C}$ which were tentatively designated as $\mathrm{A}-\mathrm{B}-\mathrm{B}$ - $\mathrm{C}-\mathrm{cells}$, respectively, were used.

As shown in Table 1, the chicken red cells which possessed $P$ antigen (the same as A6 of MCDERMID ${ }^{6}$; OKADA et al.$\left.^{7}\right)$ in A system of blood types were strongly agglutinated by normal cattle sera with a few exceptions. The similar relations were obtained in mouse sera also.

2. Changes in the frequency of appearance of natural agglutinins with age

The mouse sera were collected at monthly interval from birth and tested for the agglutinability of $\mathrm{A}_{-}^{-}, \mathrm{B}^{-}$and $\mathrm{C}-$-cells, respectively. The results were shown in Figure 1. There were no appearant strain differences in the sera of one month old mice. That is, in all mouse strains of this age, A-cell agglutinins appeared in over two third of mice, but B- and $\mathrm{C}$-cell agglutinins appeared in low frequency. When the age of mice increased, significant strain differences were observed.

Namely, in five strains of mice ( $\mathrm{KK}, \mathrm{NC}, \mathrm{C} 57 \mathrm{BL}, \mathrm{DDK}$ and BS), the incidence of agglutinins for A-cells was high at all ages examined. And the incidence of agglutinins for B-cells showed low and it increased with age, and reached to maximum at 10 month old, and which was lower than for A-cells. The incidence of agglutinins for $\mathrm{C}$-cells showed lower than for B-cells and increased in parallel with the curve shown for B-cells. In AIII mice, the incidence of agglutinins for A-cells showed high frequency but those for B-and C-cells were very low. On the other hand, AY strain showed relatively high incidence of agglutinins for A-cells at one month of age and the incidence decreased with the growth. The incidence of agglutinins for $\mathrm{B}$ - and $\mathrm{C}$-cells was low in this strain.

These facts indicated that the normal mouse sera contained three agglutinins (tentatively designated as A-, B- and C-cell agglutinins) and that these agglutinins occurred in a stepwise order, that is, A-cell agglutinin was high frequency, B-cell agglutinin middle, and C-cell 
Natural agglutinins in mouse sera

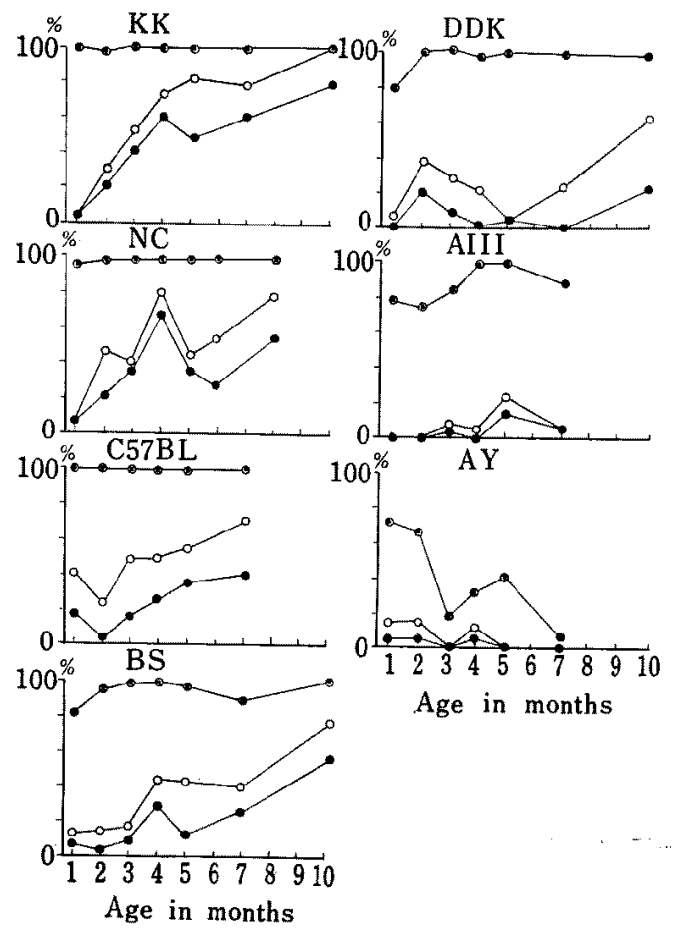

Fig. 1. Changes in frequency of occurrence of natural agglutinins for $\mathrm{A}-, \mathrm{B}-$ and $\mathrm{C}$-cells with age of mice $\odot-\odot: A-c e l l, \bigcirc-O: B-c e l l$ and $-\bullet$ : C-cell agglutinin. Frequencies in per cent is shown in vertical and age in months is shown in horizontal axis.

agglutinin low.

There was no significant sex difference in the frequency of appearance of natural agglu. tinins for A-, B- and C-cells in sera of seven inbred strains of mice.

3. The relations among A-, B- and C-cell agglutinins

To elucidate the relations among three agglutinins, the cross absorption test was carried out with the pooled sera of KK mice, which contained three types of agglutinins (Table 3). The absorption with A-cells removed not only A-cell agglutinin but also B- and C-cell agglutinins. When the sera were absorbed with B-cells, the absorbed serum agglutinated only A-cells but did not $\mathrm{B}-$ and $\mathrm{C}-$-cells, because $\mathrm{B}-$ and $\mathrm{C}$-cell agglutinins were removed. Absorp.

Table 3. Absorption test of pooled KK mouse sera which contains three, A-, B- and C-cell agglutinins with chicken red cells

\begin{tabular}{cccc}
\hline & \multicolumn{4}{c}{ Agglutination titers of sera with test cells of } \\
\cline { 2 - 4 } & NG-A & NG-B & BM-C \\
\hline Unabsorbed sera & 32 & 4 & 4 \\
Absorbed with & & & \\
A-cells & 0 & 0 & 0 \\
B-cells & 8 & 0 & 0 \\
C-cells & 16 & 4 & 0 \\
\hline
\end{tabular}


Table 4. Agglutination types of mouse sera which are classified as results of existence or absence of the three agglutinins

\begin{tabular}{lcccccccccc}
\hline \hline \multirow{2}{*}{$\begin{array}{c}\text { Strains of } \\
\text { mice }\end{array}$} & \multirow{2}{*}{$\begin{array}{c}\text { No. } \\
\text { tested }\end{array}$} & \multicolumn{10}{c}{ ABC } & AB & AC & BC & A & B & C & 0 \\
\hline KK & 102 & 56 & 18 & 0 & 0 & 28 & 0 & 0 & 0 \\
& & $(54.9)^{*}$ & $(17.6)$ & $(0)$ & $(0)$ & $(27.5)$ & $(0)$ & $(0)$ & $(0)$ \\
NC & 109 & 51 & 16 & 0 & 0 & 42 & 0 & 0 & 0 \\
& & $(46.8)$ & $(14.7)$ & $(0)$ & $(0)$ & $(38.5)$ & $(0)$ & $(0)$ & $(0)$ \\
C57BL & 167 & 46 & 46 & 0 & 0 & 75 & 0 & 0 & 0 \\
& & $(27.5)$ & $(27.5)$ & $(0)$ & $(0)$ & $(44.9)$ & $(0)$ & $(0)$ & $(0)$ \\
BS & 126 & 28 & 22 & 0 & 0 & 72 & 0 & 0 & 4 \\
& & $(22.2)$ & $(17.5)$ & $(0)$ & $(0)$ & $(57.1)$ & $(0)$ & $(0)$ & $(3.2)$ \\
DDK & 128 & 17 & 25 & 0 & 0 & 85 & 0 & 0 & 1 \\
& & $(13.3)$ & $(19.5)$ & $(0)$ & $(0)$ & $(66.4)$ & $(0)$ & $(0)$ & $(0.8)$ \\
AIII & 120 & 8 & 5 & 0 & 0 & 99 & 0 & 0 & 8 \\
& & $(6.7)$ & $(4.2)$ & $(0)$ & $(0)$ & $(82.5)$ & $(0)$ & $(0)$ & $(6.7)$ \\
AY & 102 & 2 & 3 & 0 & 0 & 21 & 0 & 0 & 76 \\
& & $(2.0)$ & $(2.9)$ & $(0)$ & $(0)$ & $(20.6)$ & $(0)$ & $(0)$ & $(74.5)$ \\
\hline
\end{tabular}

* Numbers in parenthases shows percentage of incidence

tion with $\mathrm{C}$-cells removed only homologous agglutinin but not $\mathrm{A}$ - and $\mathrm{B}$-cell agglutinins.

The distribution of three agglutinins in seven inbred strains of mice was examined with normal sera of adults of more than 3 months of age. All the mouse sera were classified into four types: $A B C, A B, A$ and $O$, as shown in Table 4. Here, $A B C$ type meant the individual serum which contained three agglutinins, $A B$ type-A- and $B-$ cell agglutinins, and so on. If the occurrence of three agglutinins was independent, mice sera would be classified into eight types theoretically as a result of combination of existence or absence of the three agglutinins. But as mentioned above, $\mathrm{AC}, \mathrm{BC}, \mathrm{B}$ and $\mathrm{C}$ types were not observed in any sera. Thus, the B-cell agglutinins never occurred without the presence of A-cell agglutinins, and C-cell agglutinins never occurred without the presence of both A- and B-cell agglutinins. These facts indicated that there were some epistatic relations among these agglutinins.

4. Strain differences in the incidence of three agglutinins

From Table 4, $\mathrm{KK}$ and $\mathrm{NC}$ showed high percentage of individuals having $\mathrm{ABC}$ type agglutinins. AIII showed low percentage of individuals which had $A B C$ and $A B$ type but showed high percentage for $\mathrm{A}$ type. In $\mathrm{C} 57 \mathrm{BL}$, BS and DDK strains, the frequencies of $\mathrm{A}$ type were almost half, while the others consisted of both $A B C$ and $A B$ types. $A Y$ showed high percentage for $\mathrm{O}$ type.

The incidence of A-cell agglutinins was shown in Figure 2-A. Although AY strain showed low incidence $(26 \%$ ), the other strains were very high (approximately $100 \%$ ). For B-cell agglutinins, KK, NC, C57BL, BS and DDK showed higher incidence than AIII and AY (Figure 2-B). For C-cell agglutinins, both $\mathrm{KK}$ and $\mathrm{NC}$ showed higher incidence than the other five strains (Figure 2-C).

From these results, seven strains of mice were classified into four groups: first group (KK and NC) showed high incidence of three agglutinins, the second group (C57BL, DDK and BS) showed high incidence of both A- and B-cell agglutinins, the third group (AIII) showed high incidence of A-cell agglutinins, and the last group (AY) was low or no incidence of three agglutinins. 
Natural agglutinins in mouse sera

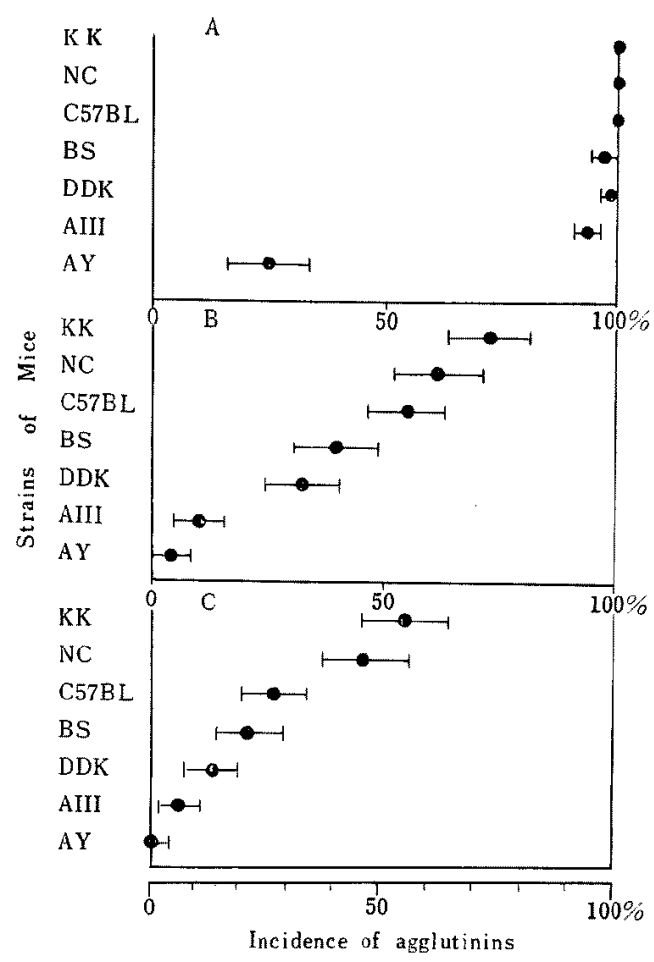

Fig. 2. Incidence of natural agglutinins for chicken RBC in sera from seven inbred strains of mice

1- $-95 \%$ confidence limits. A: natural agglutinins for-A-cells, $B$ : natural agglutinins for $B$-cells and $C$ : natural agglutinins for C-cells.

\section{Discussion}

BRILEs et $a l .{ }^{1)}$ reported that the antigens produced by two alleles of A23 and A8 in A system reacted strongly with normal cattle serum, and that there was a distinct dosage effect. In this study, the red cells which showed strong agglutination with almost all mouse sera possessed $P$ antigen in $A$ system. It may be supposed that the agglutination reactions of chicken red cells with mouse and cattle sera are similar. But there were a few exceptions that the red cells possessing $P$ antigen did not agglutinate or agglutinated weakly. These exceptions might be attributed to confusion in identifying true $P$ antigen because a closed linkage between $\mathrm{A}$ and $\mathrm{E}$ systems.

The appearance of natural agglutinins for chicken red cells was fluctuated with the age of mice. In five strains of mice, the incidence of A-cell agglutinin reached already almost. $100 \%$ in one month of age and that of $\mathrm{B}$ - and $\mathrm{C}$-cell agglutinins increased with age. In AIII mice, the incidence of A-cell agglutinin increased with age. Namely, in these strains it was suggested that the appearance of these agglutinins might increase with the accumulation of antigenic stimulus and (or) with the development of the immunological maturation of mice. But in AY mice, a reverse phenomenon was observed: the incidence of A-cell agglutinin decreased with age. The reason why this exception occurred in AY is not known. 


\section{KANEMAKI}

It is apparent that there existed a stepwise order of three agglutinins. This was confirmed from the following facts: (1) the $A B C, A B, A$ and $O$ types were observed in the mouse sera, but the other types, $\mathrm{AC}, \mathrm{BC}, \mathrm{B}$ and $\mathrm{C}$, did not; (2) A-, B-and $\mathrm{C}$-cell agglutinins were removed by absorption with $\mathrm{A}$-cells, $\mathrm{B}$ - and $\mathrm{C}$-cell agglutinins were removed by absorption with B-cells, and C-cell agglutinin was removed by absorption with C-cells; (3) in five strains of mice, A-cell agglutinin was present in almost $100 \%$ animals of all ages, and the incidence of $\mathrm{C}$-cell agglutinin increased, being accompanied with $\mathrm{B}$-cell agglutinin, with the growth.

STIMPHLing ${ }^{10)}$ showed significant sex difference in C57BL mice with respect to both sheep and chicken agglutinins, that is, females had higher titers than males. KIRSHвOM and HoECKER ${ }^{4}$ reported that females showed higher percentage than males in regard with natural anti-human red cells in C57BL mice. But STERN et al. ${ }^{8}$ reported no sex difference in mean titer levels of anti-sheep and -chicken cell agglutinins in C57BL mice. In the present study, there was no significant sex difference in the incidence of three agglutinins in all mouse strains. These different results could be possibly attributed to difference of red cells.

When the factors mentioned above, the sort of red cell antigen, age and sex of mice, were considered, it was made possible to classify the mouse strains by using the difference of natural agglutinins for chicken red cells. Seven mouse strains were classified into 4 groups by the significant difference of the incidence of each agglutinin. This may suggest the presence of the genetical control of the production of natural agglutinins of the mouse. This result agreed with the conclusion of STERN et al. ${ }^{21}$ who showed the presence of the genetical control of natural anti-sheep and -chicken agglutinins.

\section{Summary}

Natural agglutinins for chicken red cells in sera of seven inbred strains of mice (KK, NC, C57BL/6, DDK, BS, AlII and AY) were examined.

1. Qualitatively different three A-, B- and C-cell agglutinins for chicken red cells were discovered in sera of inbred mice. These three agglutinins appeared with a stepwise order.

2. Age of the mice was a main factors which influenced the incidence of natural agglutinins within a strain when the same red cells were used as antigen. In the sera of one month old mice, there were no apparent strain differences. In six strains of mice, the incidence of natural agglutinins increased with age, but the reverse age effect was found in AY mice. Within a strain, sex did not influence the incidence of agglutinins.

3. When the mouse strains were distinguished by the significant difference in the incidence of each agglutinin, the seven strains can be classified into four groups. $\mathrm{KK}$ and NC had high incidence of three, A-, B- and C-cell agglutinins, C57BL/6, DDK and BS had high incidence of both A- and B-cell agglutinins, AIII had high incidence of only A-cell agglutinin, and AY had low or no incidence of all agglutinins.

\section{Acknowlegement}

The author wishes to express the deepest thanks to Prof. K. Kondo for the preparation of mice and chickens and for his helpful guidance, and also to Dr. Y. Fujı for the permission of drafting his data of blood types of chicken and for giving his helpful opinions of this work. 
Thanks are also due to Dr. T. ABE of National Institute of Animal Industry for review of the manuscript.

\section{References}

1) Briles, W.E., R.W. Briles and M.R. Irwin (1953) Genetics, 37: 359-369.

2) Fujo, Y., Y. Kanoh and K. Kondo (1970) Jap. J. Genet., 45: 23-33.

3) Hayakawa, J. and K. Kondo (1965) Bull. ExptI. Anim., 14: 18-22.

4) Kirshbom, I. and G. Hoecker (1963) Nature, 200:687-688.

5) Kondo, K., K. Nozawa, T. Tomita and K. Esaki (1957) Bull. Exptl. Anim., 6: 107-117.

6) McDermid, E.M. (1964) Fox Sang., 9: 249-267.

7) Okada, I., Y. Hachinohe and E. M. McDermid (1967) Proc. Jap. Poultry Sci. Associ. Jap. Brench W.P.S. A. (Nov,, 1967)

8) Stern, K. and I. DAvidsohn (1954) J. Immunol., 72: 209-215.

9) Stern, K., S. Brown and I. Davidsohn (1956) Genetics, 41: 517-527.

10) Stimphling, J. H. (1960) J. Immunol., 85: 530-532.

近交系マウスの正常血清中に含まれる抗一ニワトリ血球凝集素

\section{印牧 美 佐 生* \\ (名古屋大学農学部)}

マウスの正常血清中に含まれる抗一ニトリ血球凝集 素について，抗原上して用いるニワトリ血球の種類，お よびマウスの月令, 性のbがいについて考虑し, 支の出 現頻度の差によって7系統のマウス (KK, NC, C57BL/ 6, DDK, BS, AIII 和よび AY) の分類岩試み，以下の 成績得た。

1. 近交系マウスの歰常血清中に， 3 系統のニワトり (ナゴヤA系, ナゴヤB系, 黑色ミノルカC系)の血球に

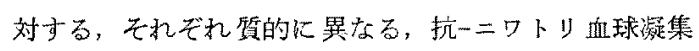
素（A，B およびC 血球㠜集素）が見出された。これら の凝集素は一定の段階性をむって発現する。すな⿰口, A血球凝集素弾独で発現するが，B血球凝集素はA， そしてC血球凝集素は $\mathrm{A}$ 京よびB各血球凝集素が存在し なければ発現しない。

2. 同一系統内の各凝集素の出現頻度は, 主としてマ
ウスの月令のるがいによって影堲された・性のちがいは

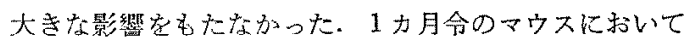
は, 凝集素の出現頻度に著しい系統差注認められなかっ

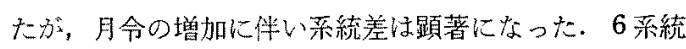
のマウスでは，月令の堌加に伴い各凝集素の出現頻度は 增加する傾向にあったが，AY系ではその逆の現象が現 われた。

3.3力月令以上のマウスについて，各㠜集素の出現頻 度の有意差の有然によって，マウスの系統定以下の如く 4 グループに分けることができた。（1）A，BおよびC血 球凝集紫を高頻度に有与る采統：KK, NC. (2) Aおよび B 血球㠜集素高頻度火有する系統: $\mathrm{C} 57 \mathrm{BL} / 6, \mathrm{DDK}$, BS. (3) A血球凝集素を高覑度に有寸る采統：AIII. (4)

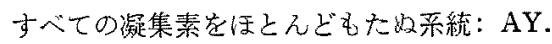

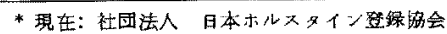

